ISSN: 2362-1303 (Paper) | eISSN: 2362-1311(Online)

JOURNAL OF ADVANCED ACADEMIC RESEARCH (JAAR)

December 2017

\title{
Does Remittance Receiving Households Prepared against Natural Disasters in Nepal?
} Gangadhar Chaudhary $^{1}$ \& Tatwa Prasad Timsina ${ }^{2}$

${ }^{1} \mathrm{PhD}$ Scholar, Mewar University, Department of Environment, Chittorgarh, Rajasthan, India

${ }^{2}$ Research Supervisor, Professor, Tribhuvan University, Kirtipur.

\section{Corresponding Author}

Gangadhar Chaudhary

Email: gdc4np@gmail.com

\begin{abstract}
The study examines the perception of remittance receiving families to consume its portion of income on building capacity and preparedness against any natural disasters in Nepal. Moreover, there is growing evidence that remittance income is consumed to improve livelihood, especially on household expenses, education, treatment and the construction of the new house or repairing existing one. The objective of this study is to analyze to what extent the poor people whose earning incomes, including remittance, prepare them to cope with the upcoming natural disasters to minimize the loss afterward. The sites were purposefully selected in different districts in Nepal to observe the way of preparedness and have vulnerable to natural disaster. The snowball sampling method was chosen to interview with open and closed questionnaires only to remittance receiving families. Similarly, the observation method was used to assess the quality and type of houses they belong. The qualitative data were processed using SPSS 20 with statistical tools as frequencies and verified with one way ANOVA test. The result showed that the remittance receiving families improved their livelihood (improving their living standard with more expenses in home, health, and education, construction, savings) It was observed that the remittance receiving families consumed income in new construction of houses and repairing to make their houses strong without consulting the technical expert or use of building codes, that rising doubt to withstand the worse impact of natural disasters mainly earthquake, flood and landslide. This study concludes that the remittance receiving household, though have better livelihood, yet they are not better prepared against the ruthless impact of any natural disasters.
\end{abstract}

\section{KEYWORDS}

Coping Capacity, Expenditure, Livelihoods, Natural Disasters, Migration, Remittance.

\section{INTRODUCTION}

Nepal is prone to disaster due to rugged topography, active tectonic process and intense monsoon made of fragile environment that makes the country vulnerable to the disasters. (Government of Nepal, 2017), indicated that Nepal stands at the top $20^{\text {th }}$ list of the most multi hazard prone countries in the world. Similarly, the country is ranked $4^{\text {th }}, 11^{\text {th }}$ and $30^{\text {th }}$ in terms of climate change, 
earthquake and flood risk, respectively among 200 countries in the world. According to (Karki, 2011), frequent natural disasters occurred. i.e. flood in the monsoon season in the Terai region, avalanches and glacier lake outburst and landslide in the hilly region, cold wave in winter seasons, epidemiology and fire in a country. It was estimated that an average two human lives are lost every day due to natural disasters. (Manandhar, 2016), informed that as per Post Disaster Need Assessment (PDNA) report, due to the 2015 April earthquake disaster, human settlement suffered a loss of 350.37 billion. Most of the adobe houses and others, constructed without introducing the building code were affected. A natural disaster is increasing in Nepal since last three decades due to rapid urbanization, uncontrolled development, degraded environment and human interventions, (DPNet-Nepal, 2013).

In another hand, the wealth inequality, low income, lack of employment, forced by natural disasters and demand for skilled and unskilled laborers from under developing countries are the main reason for the migration of people. Further, the globalization and liberalization of migration policies play a vital role in this regard, (UN, 2011). The main reason of migration of poor people is unemployment and insecurity from natural and man-made disasters in Nepal. It is well understood that poverty causes disasters and disaster causes poverty. The poor people due to the lack of resources have not coping capacity to natural disaster. (Narsey Lal, Singh, \& Holland, 2009), reported that, after the occurrence of natural disaster, the poor often lose their property and assets on which they are surviving. Therefore the poor unwillingly migrates from their residence for their survival. The country was adversely affected by the conflict for decades, which impacts the socioeconomic development. The poor people who are engaged as a labour in the agricultural activity in rural areas have not sufficient capacity to cope with the poverty. They are at risk and consume less because they could not cope with the income. (Sugiyanto, Kusumastuti, \& Donna, 2012 , p. 1). The factors which make the Nepali people poor are low, economic growth, low agricultural production, lack of non-agricultural employment opportunities, historical inequalities, low levels of economic infrastructures, high population growth, degraded environment and bad governance, (UNDP, 2001).

Similarly, the poor people migrate to the disaster prone area and work in marginal lands. Their income is severely affected and food insecurity compelled them to migrate elsewhere to earn more income. The people in upland areas of Nepal are very poor. (Upadhyaya, 2010). They migrate in urban and in plain areas 'are in the search of employment. National census 2001 defined the migration as "a person who moves either from his/her birthplace to another area or keep moving stepwise or circularly by changing his/her residence more or less frequently being either seasonal or permanent migration, depending upon the duration of migration and reasons for migration within defined geographic area". The common trend of migration is internal and International migration in Nepal. Traditionally, the people go to the terai and urban area. Mostly, the migration took place in India and Tibet (Sharma, Pandey, Pathak, \& Sijapati, 2014, p. 1). When Nepal entered into the global economy, the people of Nepal have a great opportunity to go to the Gulf countries for the employment. As data gathered by (Sharma at el, 2014) reported as the number of international migration has increased significantly over the past 60 years. About 200,000 people 
migrated aboard in 1950 which increased to 2 million in 2011. In the research conducted by (Ratha \& De, 2012) stated that developing countries received more than 325 billion dollars from remittance in 2010. They quoted statement of Rathi, 2003 and yang 2011 that large amount of remittance was consumed by family and their dependents. Now the remittance from migrants becomes the main source of better livelihood for the people. (Bhandari, 2004), examined the relative deprivation of migration in Nepal. Bhandari exposed that people having no land or less land were compelled to migrate than those having more agricultural land. (De, Gaillard, \& Friesen, 2013), also supported that coping capacity and different strategies are used to face natural disaster which is originated from the better livelihood. Thus to cope from disaster, the poor people always used livelihood diversification. It means poor people improve their livelihood by asserting some activities and strengthen the social support capacities. In this case, Remittance is one of the important strategies to make income for the poor people.

Remittances refer to the money and goods that are transmitted to households by migrant workers working outside of their origin communities. (Cuecuecha \& Adams, 2010, p. 1626). They made two findings; Remittance receivers spend less in the consumption on food compared with those who did not receive any remittance. Secondly, they spend more on education and housing. The finding supports that remittance can help increase the level of investment in human and physical capital in remittance receiving countries. However, the remittance receivers have better opportunity to consume the remittance in different ways. But one question arises "Are the people capable to consume on preparedness against the natural disasters using remittance?" How they build their capacity to respond the natural disasters? These are the questions, I tried to explore through this research.

On the basis of evidence from Pakistan Occupied Kashmir, by (Suleri \& Savage, 2006), it seems that the remittance receiver spent all the money they got from the remittance sender. But the remittance sender saved some money for the upcoming emergency. They further added that $43 \%$ of recipient spent in daily household expenses. $32 \%$ of the recipient paid the debt, refurbished the home, pay wedding expense's , arrange dowries for their children and $20 \%$ used the remittance in house construction and investment in real state. (Mohapatra \& Ratha, D, 2009), found that households in Burkina Faso, Africa, strengthen their houses with concreting the roof and wall, made proper drainage system owing mobile phone and living in parceled area that contribute considerably to reduce the probability of floods or to face a natural disaster as cited in (Tapsoba,2017,p, 24). (Manandher, 2016) found that remittance dependent households consumed a large amount of their remittance in construction of houses with poor quality those were vulnerable to earthquake. (Tapsoba, 2017), pointed out that remittance, poverty and disaster were linked with each other. He found the important result that remittances have a negative impact on poverty and it has a higher impact on the resilience of those households had experienced disasters in the past. There are many literatures explained about the relationship between remittance and disasters which experienced in the past, but found limited research on the use of remittance in preparedness and coping capacity against any disaster. 
The main objective of this research is to assess the role of the remittance on the preparedness of the natural disaster in Nepal. There is inadequate research on how the remittance consumption contributes in preparedness in natural disasters in case of Nepal. A key contribution of this paper is to explore systematically the impact of remittance on the preparedness of natural disaster that will reduce the extent of damages. Remittance is the most important resource for the community people to improve their livelihood which enhance their coping capacity to respond with any upcoming disaster. This study will help the policy maker and decision maker to support such community in the consumption of their income in coping with natural disaster scientifically. Remittance is an important resource in Nepal and can occupy a prime role in ex-ant disaster risk resilience. We could not find an intensive effort by government, humanitarian or development partners to make a consumption process of remittances for resilience and preparedness for any disaster. This study explores the Nepalese migrant community, their use of remittances for mitigation of probable risk of natural disaster.

\section{MATERIALS AND METHODS}

Remittances are typically helpful to meet specific needs of the respondents' family members and thus tend to increase their standard of living. In lower class or poor households, they may finance their remittances to fulfill their basic needs, such as in consumption, housing, children's education and health care and to pay for the loan. I focused this study on different community resided in Nepal. The study was conducted in Kailali (Hasuliya \& Lalbadi Village bodies and Belauri Nagarpalika) in the far western development region. Similarly, in the Central region, Nuwakot (Manakamana Village Body) and Bhaktapur (Nashiksthan) were selected and Saptari (Hanuman Nagarpalika) and Sunsari (Koshi Village Body) districts in the eastern region at village level as shown in figure 1 . These sites were chosen because their proximity to nearby river which made them at the risk of flood and earthquake. In Bhaktapur and Nuwakot, the households were suffering from earthquake and landslides and have high levels of migration.

I, purposeful and randomly sampling with snowball method and selected five districts having prone to natural disasters, mainly flood, Earthquake, windstorm and Landslides. Altogether 149 Households visited for the study in 13 villages of five districts. The observation approach was

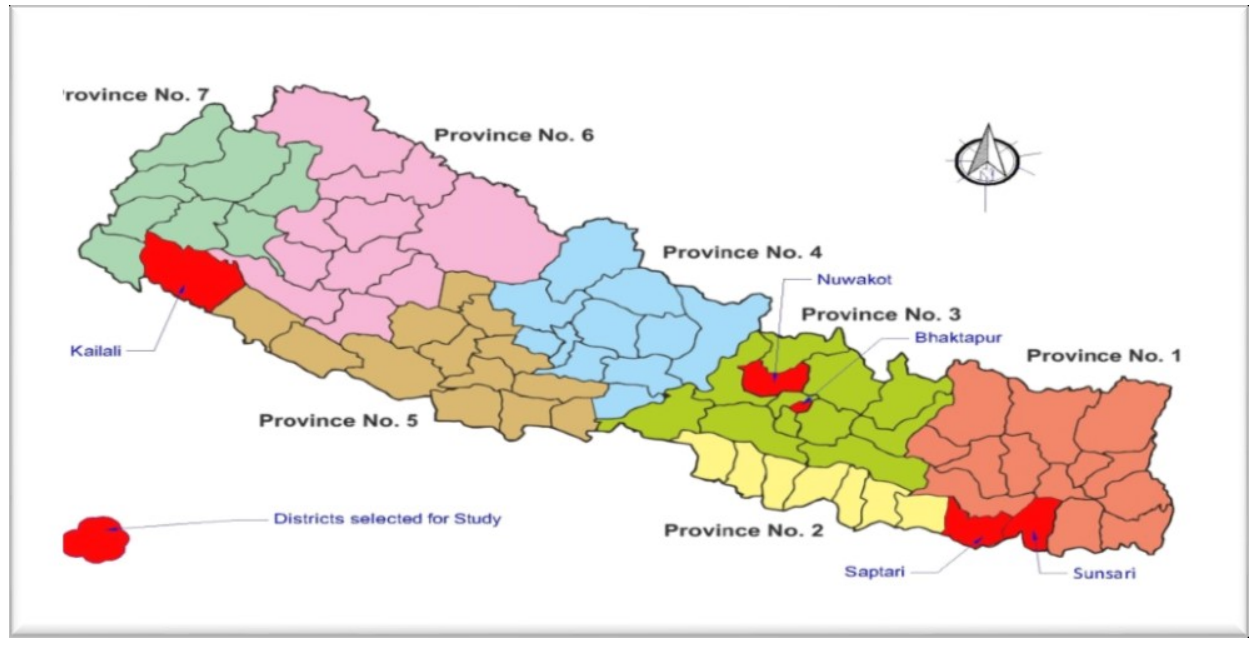


used to know the situation of their preparedness towards the natural disasters. The open and closed questionnaires were developed. The face to face interview technique was adopted to get all the information with remittance receiving households. These households were interviewed with structured questionnaires. The data collected were systematically processed and analyzed in different statistical tools using the SPSS 20 version software. The qualitative data were processed, edited and verified. The outcome results were tabulated and presented in different graphs. The hypothesis was tested with One Way ANOVA test.

\section{RESULTS AND DISCUSSION}

As discussed in the introduction chapter, the study examines the role of remittances play to prepare the remittance receiving Households (HHs) against natural disasters mostly occurred in their neighborhood.

\section{Effect of natural disasters on remittance receiving HHs.}

As per the response by the remittance receiving HHs in the study areas, the HHs faced multidisasters as presented in Figure 2. Only 146 respondents ticked at least one of the options and rest 3 respondents skipped the questions. These 146 respondents ticked 374 boxes in total. On an average, more than 2 ticks per respondents.

Obviously, people faced natural disasters, most. This shows that mostly people were affected by flood followed by an earthquake. In the Saptari district, the people responded that they frequently faced flood, Fire and windstorm disasters every year and also experienced an earthquake. These disasters affected their life and properties. Likewise, in Nuwakot district, people experienced earthquake, Landslide and Flood, which

\% of HHs Affected by Natural Disaster

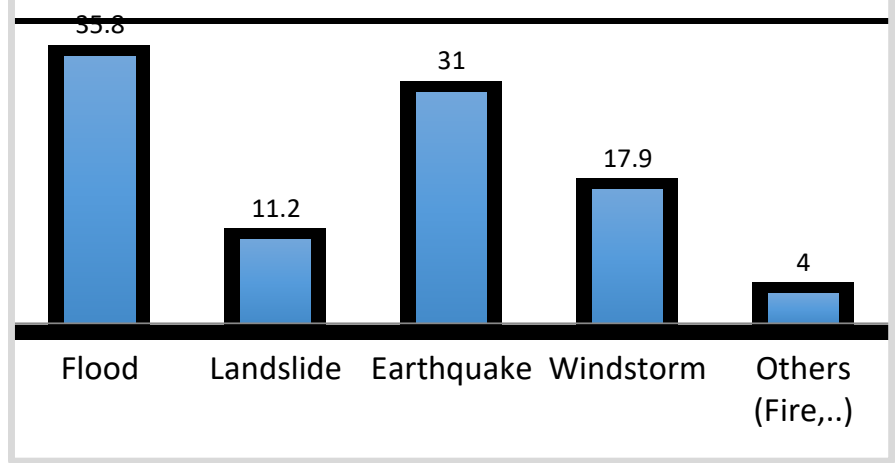

Figure 2. Disaster affected HHs damaged their property and mostly lost life. The earthquake in April 2015 was consequence the landslide in hilly areas. Sometimes, they faced flood as most of the HHs were built along the bank of the river.

\section{Capacity of Remittance receiving HHs to cope natural disasters.}

\section{Education}


It is noted from the Figure 3 that the education level of the remittance receiving family is set to typically higher schooling only. Few percentage of remittance receiving $\mathrm{HHs}$ had above higher education which was confined to urban areas. (i.e. +2). During the field visit, I found literate $\mathrm{HHs}$ members and most have primary education. The education of Households can play an important role in preparing and preventing natural disasters. It helps to take an appropriate action to cope with the disasters. It developed the capacity of decisions making against any risk to them. It is the awareness and

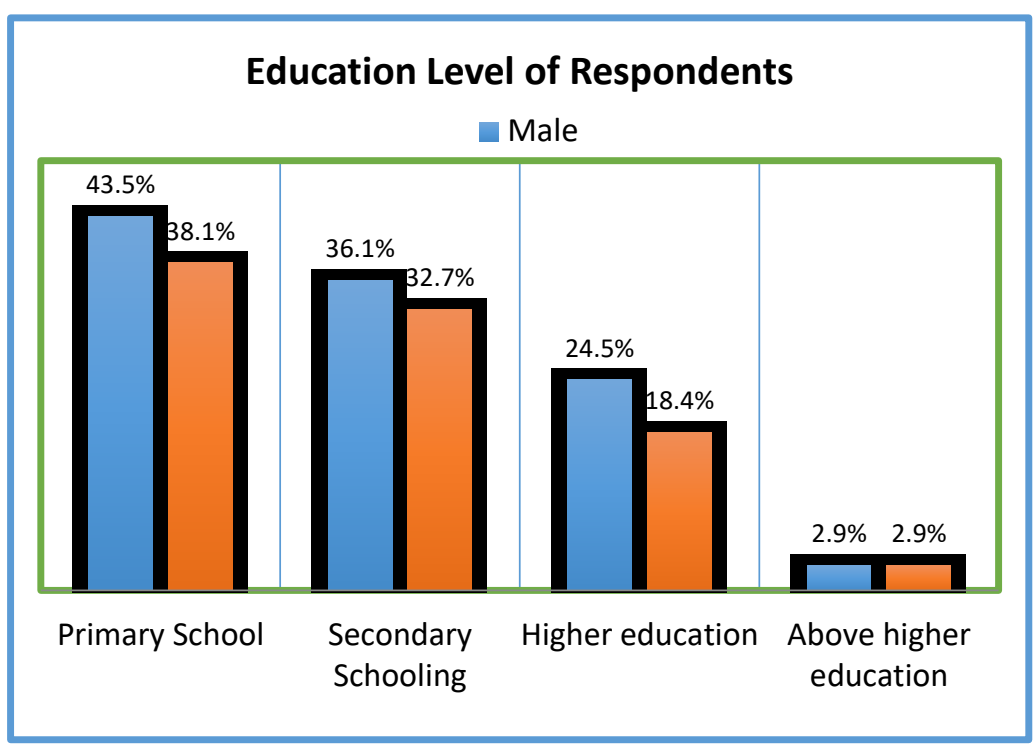

Figure 3. Education level of Remittance receiving HHs education for people to reduce loss of life and damages from natural disasters. It contributes past experience with recent developments in technology to combat disasters. The people must know in advance that protective action can be taken during disasters which contribute past experience with recent developments in technology to combat disasters. Many research findings stated that on average remittance receiving households make higher investments in health and education.

\section{Income Pattern of Remittance receiving households}

The remittance receiving households responded that they had multiple income sources as shown in Figure 4. Among them, most of the HHs received income from remittance which is higher among other sources. Similarly, agricultural farming is the second source of income. It means most of the HHs received income from remittance as a prime income source which dramatically changed the livelihood. The targeted respondents were poor and marginalized that means most were dependent on agriculture profession with small

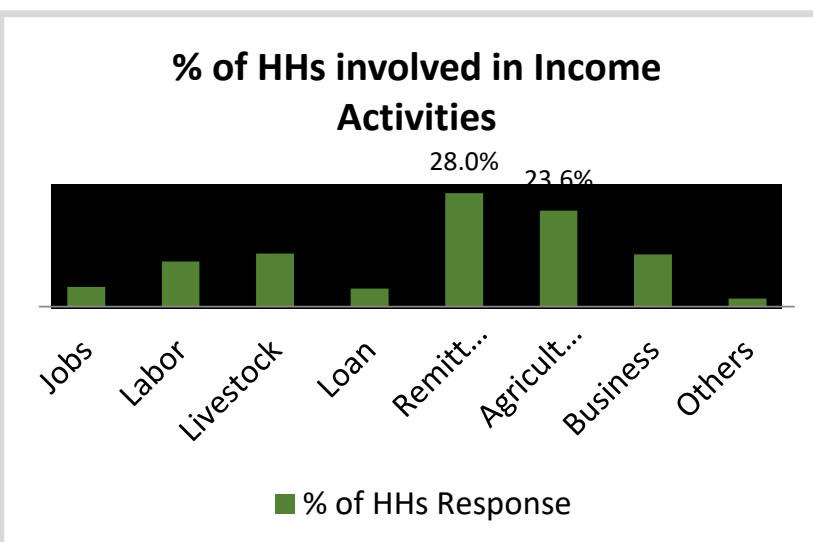

Figure 4. Multiple Income sources of HHs land size. Livestocks and Business were the other income sources. The Business was small and selling their agricultural products in the local (hat bazaar) markets. A Small portion of the HHs member was associated with the job.

\section{Pattern of Expenses of remittance}


Most of the respondents informed that they used their income, including remittance on household expenses. The Figure 5 shows that remittance receiving HHs consumed income in daily household expenses (food, cloth) and in education. The Figure 5 also indicates that the HHs consumed their income in the treatment of their family members. Some portion of their income used in the house construction and investment in real estate. But the migrant worker initially got a loan to underwrite the costs of migration. They had to repay the loan as soon as they started earning. After completing the repayment of the loan, they started to save the money to build houses, purchase land and so on. The modality of the expenses changed in the due course of the time.

\section{Losses due to catastrophe}

All of the respondents experienced the disaster in the study areas. The Figure 6 shows that frequently occurrence of natural disaster in study area was Earthquake, Flood, Windstorm and Fire. Mainly houses and livestock stable were affected with the impact of these natural disasters. The disaster caused damage of the house and stables, death or sickness of the people, death or injury of livestock's and spoil of the crops. Many respondents stated that during the flood, the source of the drinking water gets contaminated and they were forced to drink the unhygienic water. Few respondents accepted that food grain storage was damaged. As the survey was limited to

HHs Expenses Pattern
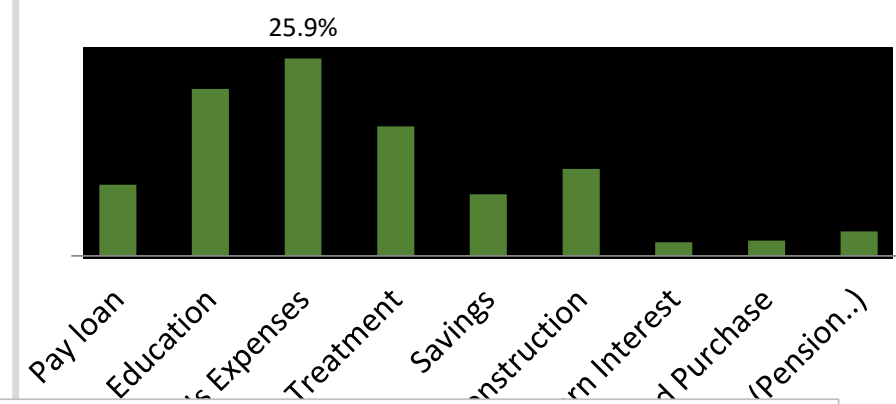

\section{Losses caused by Natural Disasters in \%}

Figure 5. HHs Expenses Pattern
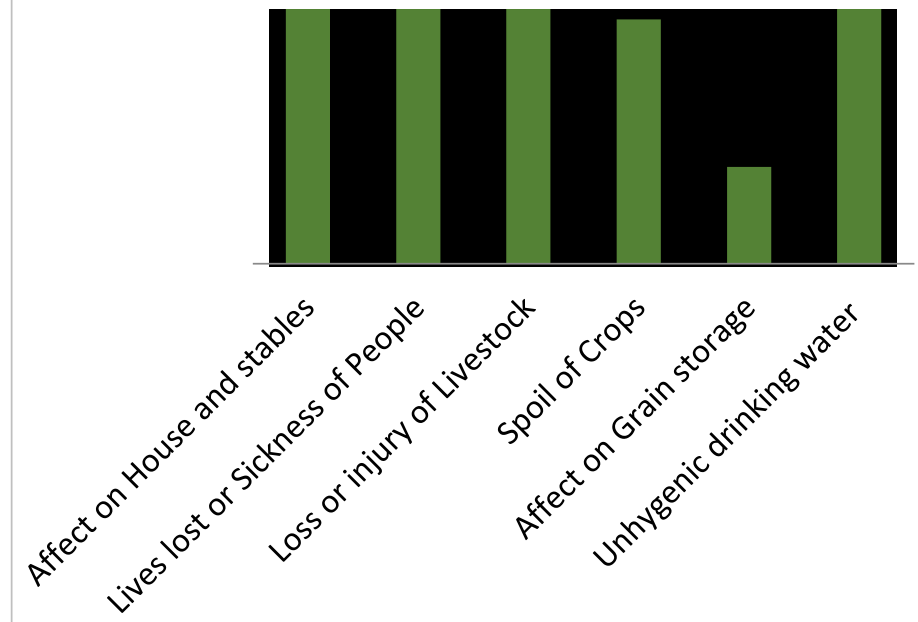
marginalize poor people those had not enough food storage to having food stored for a year. Gorkha earthquake 2015 was the most recent disaster experienced in the country. Similarly, destruction due to landslides and floods are frequent disastrous effect to the people every year.

\section{Preparedness for disaster}


The respondents summarized their preparedness against natural disaster as they experienced in past years. The Figure 7 shows that the respondents put emphasis on the identification of safe place or evacuation in place on any disaster happened. Many HHs responded that after the disaster they repaired or retrofitted their damaged houses. Likewise, some of the respondents informed that they had protected their land with a small earth bund against a flood which strength is not sufficient to withstand the affect of water current. Considerably, they prepared storage of basic and essential goods (Tarpaulin, torchlight, kitchen utensils.) to cope with the disasters. Other respondents declared that they had kept food safe in-house. Some of the respondents agreed that they use the remittance to retrofit their houses or make a new. But mostly, respondents confirmed that they had built or repaired their houses from the source of remittance income. When they were asked whether they consulted with the technical person about the construction of the houses to integrate earthquake measures, protection from flood or windstorm and fire, few respondents affirmed that they had consulted with the engineer with their own initiation limited to the urban area of the Bhaktapur. But mostly respondent agreed that they constructed their houses as per the knowledge of the local contractors having no any proper (equipped with technology to withstands affect of any disasters) skills to build a house.

Table 1. Testing the Preparedness against Natural Disaster of HHs

\begin{tabular}{|l|l|r|r|r|r|r|}
\hline \multicolumn{2}{|c|}{ Particulars } & $\begin{array}{c}\text { Sum of } \\
\text { Squares }\end{array}$ & df & \multicolumn{1}{c|}{$\begin{array}{l}\text { Mean } \\
\text { Squar } \\
\text { e }\end{array}$} & F & Sig. \\
\hline \multirow{2}{*}{$\begin{array}{l}\text { Preparedness- Storage of } \\
\text { Food }\end{array}$} & Between Groups & .010 & 1 & .010 & .159 & .691 \\
\cline { 2 - 7 } & Within Groups & 9.310 & 145 & .064 & & \\
\cline { 2 - 7 } & Total & 9.320 & 146 & & & \\
\hline \multirow{5}{*}{} & Between Groups & .056 & 1 & .056 & .233 & .630 \\
\hline & Within Groups & 34.611 & 145 & .239 & & \\
\hline
\end{tabular}


ISSN: 2362-1303 (Paper) | eISSN: 2362-1311(Online)

JOURNAL OF ADVANCED ACADEMIC RESEARCH (JAAR)

December 2017

\begin{tabular}{|c|c|c|c|c|c|c|}
\hline $\begin{array}{l}\text { Preparedness- Strong } \\
\text { House Construction or } \\
\text { Repair }\end{array}$ & Total & 34.667 & 146 & & & \\
\hline \multirow{3}{*}{$\begin{array}{l}\text { Preparedness- Protection } \\
\text { of Land }\end{array}$} & Between Groups & .001 & 1 & .001 & .004 & .947 \\
\hline & Within Groups & 36.611 & 145 & .252 & & \\
\hline & Total & 36.612 & 146 & & & \\
\hline \multirow{3}{*}{$\begin{array}{l}\text { Preparedness- Installation } \\
\text { of Early Warning System }\end{array}$} & Between Groups & .010 & 1 & .010 & .074 & .786 \\
\hline & Within Groups & 20.071 & 145 & .138 & & \\
\hline & Total & 20.082 & 146 & & & \\
\hline \multirow{3}{*}{$\begin{array}{l}\text { Preparedness- } \\
\text { Development of Coping } \\
\text { mechanisms }\end{array}$} & Between Groups & .222 & 1 & .222 & 1.218 & .271 \\
\hline & Within Groups & 26.444 & 145 & .182 & & \\
\hline & Total & 26.667 & 146 & & & \\
\hline \multirow{3}{*}{$\begin{array}{l}\text { Preparedness-Saving in } \\
\text { Bank }\end{array}$} & Between Groups & .073 & 1 & .073 & .302 & .583 \\
\hline & Within Groups & 34.825 & 145 & .240 & & \\
\hline & Total & 34.898 & 146 & & & \\
\hline \multirow{3}{*}{$\begin{array}{l}\text { Preparedness- Life \& Non } \\
\text { Life Insurance }\end{array}$} & Between Groups & .010 & 1 & .010 & .098 & .754 \\
\hline & Within Groups & 15.024 & 145 & .104 & & \\
\hline & Total & 15.034 & 146 & & & \\
\hline \multirow{3}{*}{$\begin{array}{l}\text { Preparedness- } \\
\text { Identification of Safe place }\end{array}$} & Between Groups & 1.389 & 1 & 1.389 & .371 & .544 \\
\hline & Within Groups & 543.278 & 145 & 3.747 & & \\
\hline & Total & 544.667 & 146 & & & \\
\hline \multirow{3}{*}{$\begin{array}{l}\text { Preparedness- Storage of } \\
\text { essential goods }\end{array}$} & Between Groups & .549 & 1 & .549 & 2.206 & .140 \\
\hline & Within Groups & 36.063 & 145 & .249 & & \\
\hline & Total & 36.612 & 146 & & & \\
\hline \multirow{3}{*}{$\begin{array}{l}\text { No any action taken- God's } \\
\text { will }\end{array}$} & Between Groups & 2.949 & 1 & 2.949 & .353 & .553 \\
\hline & Within Groups & $\begin{array}{r}1210.73 \\
8\end{array}$ & 145 & 8.350 & & \\
\hline & Total & $\begin{array}{r}1213.68 \\
7\end{array}$ & 146 & & & \\
\hline
\end{tabular}

The one way ANOVA model was used to analyze how the remittance income influenced the preparedness against the natural disasters by the remittance receiving households. Was there any significant difference between remittance income and preparedness against the natural disasters? The descriptive statistics associated with the expenditure of remittance income across the ten categories of preparedness against natural disaster is illustrated in table 1. From the table we found that all ten factors (storage of food $<\mathrm{F}=0.159, \mathrm{p}=0.691>$, strong house construction or repair $<$ $\mathrm{F}=0.233, \mathrm{p}=0.630>$, Protection of land $<\mathrm{F}=.004, \mathrm{p}=0.947>, \quad$ Installation of $\mathrm{EWS}<\mathrm{F}$ $=0.074, \mathrm{p}=0.786>$, Development of Coping mechanism $<\mathrm{F}=1.218, \mathrm{p}=0.271>$, Saving in Bank $<F=0.302, p=0.583$, Life \& Non Life Insurance $<F=0.098, p=0.754>$, Identification of 
Safe place $<\mathrm{F}=0.371, \mathrm{p}=0.544>$, Storage of essential goods $<\mathrm{F}=2.206, \mathrm{p}=0.140>$, God's will $<\mathrm{F}=0.353, \mathrm{p}=0.553>$ ) are insignificantly associated with remittance income. Hence, we fail to reject the null hypothesis. Thus, we conclude that there is no statistically significant relationship between the two variables (Remittance income and Preparedness). The result agreed and supported by the outcome of (Manandher, 2015).

\section{Integration of disaster mitigation measures in construction or repair of houses.}

The respondents were asked about the mitigation measures of the affect of disaster categorically while constructing or repairing the houses. More than $60 \%$ of the respondents do not know the mitigation measures applicable to the construction or repair of houses against the disaster. Some of the respondents acknowledged that they know some mitigation measures applicable to the construction of the house, but not adopted. Less than $4 \%$ of the respondents stated that they had applied disaster mitigation measures as raising plinth level in a flood prone area, strengthening house with the concrete pillars, beams, slabs and wall with increasing dimensions and thickness with horizontal and vertical concrete bands.

\section{Observation}

During the field visit, I observed the type of construction of the houses of the respondents as presented in Figure 8. Most of the respondents used concrete as roofing materials. Similarly, many have their houses made of brick masonry as a wall. Many respondents used either mud or concrete as floor materials. Building materials used in house to potentially reveal how prepared households are in the case of natural catastrophe. Concrete homes are more resilient against natural disasters while houses made of mud, dry stone masonry, bamboo are more susceptible to devastation in the case of catastrophes. (Mohapatra and Ratha, D,

Types of House of Respondents in \%

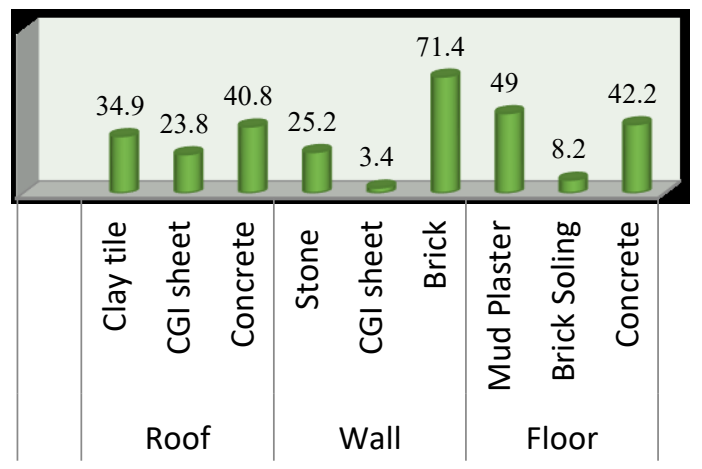

Figure 7. Materials used in houses of respondents 2009) found that the remittance receiving households in Burkina Faso tends to dwell in a strong house having constructed with concrete, making them resilient to disasters. From the Figure 8, we can conclude that there were tendencies of remittance receiving HHs to live in a strong house as we found in the observation and respondents expenses their remittance in building the concrete house. The peoples, line agencies and the government of Nepal realized to make strong houses to 
ISSN: 2362-1303 (Paper) | eISSN: 2362-1311(Online)

JOURNAL OF ADVANCED ACADEMIC RESEARCH (JAAR)

December 2017

withstand the effect of catastrophes experiencing the devastating earthquake in April 2015, enforcing the Building Code in many municipalities.

\section{CONCLUSIONS}

This article has given an analysis of how migrant remittances respond in the preparedness and developed their capabilities to cope with the natural calamities. Hence the study highlights the need to concentrate on raising awareness to use some part of the income of remittance receiving households to prepare themselves as to cope with any kinds of natural calamities. From the study, we found that the households use their income to meet their housing expenses, education of the children, and treatment of their family members, repair and construction of houses. It is one pace of the preparedness, transforming the type of house from old adobe type construction into concrete houses as the symbol of improving livelihood. The structure of houses without knowledge of disaster resilient technology invites further risks of higher disasters to the inhabitant. Another outcome of this research is that the remittance receiving households were reluctant to prepare for the upcoming disasters. This is very alarming situation of the vulnerable country like Nepal which is supposed to be a hub of all most all types of disasters except Tsunami.

The study disclosed that though the people has developed their coping capacity against any natural disaster to some extent, knowingly or unknowing they are not prepared and lacking. The remittance receiving households are getting educated, improving their livelihood, building a house, locating safe places for evacuation after the disaster. But the sustainable aspects of developing capacities are installing an early warning system, saving money in bank, storage of essential food and equipments, making living and non living insurances, training on capacity building, leadership and management, technology on protection of lands and other properties. The Government, line agencies, Humanitarian organization and other stakeholders must take initiation to aware people to make them better prepare against disasters affect of the natural hazards.

\section{REFERENCES}

Attzs, M. (2008). Natural Disasters and Remittances, Exploring the Linkages between Poverty, Gender,and Disaster Vulnerability in Caribbean SIDS. Finland: UNU World Institute for Development Economics Research (UNU-WIDER).

Bhandari, P. (2004). Relative Deprivation and Migration in an Agricultural of Nepal. Population and Environment, Vol. 25, No. 5 , 475-499.

Cuecuecha, A., \& Adams, J. R. (2010). Remittances, Household Expenditure and Investment in Guatemala. World Development Vol. 38, No. 11, 626-1641.

De, L. L., Gaillard, J. C., \& Friesen, W. (2013). Remittances and disaster:a review. International Journal of DisasterRiskReduction 4(2013)34-43 , 34-41.

DPNet-Nepal, D. (2013). Nepal Disaster Report 2013, Focus on participation and Inclusion. Kathmandu, Nepal: Ministry of Home Affars, Government of Nepal; and Disaster Preparedness Network Nepal (DPNet-Nepal).

Karki, M. B. (2011). Disaster: A challenge to Respond in Nepal. PRASHASAN, pp. 135-142. 
ISSN: 2362-1303 (Paper) | eISSN: 2362-1311(Online)

JOURNAL OF ADVANCED ACADEMIC RESEARCH (JAAR)

December 2017

Manandhar, B. (2016). Remittance and earthquake preparedness. International Journal of Disaster Risk Reduction 15 , 52-60.

Ratha, D., \& De, P. K. (2012). Impact of Remittances on Household Income, Asset and Human Capital: Evidence from Sri Lanka. Migration and Development, 1(1), 2012-10-25 , 1-44.

Sharma, S., Pandey, S., Pathak, D., \& Sijapati, B. (2014). State of Migration in Nepal. Kathmandu, Nepal: Center for the Study of Labour and Mobilty.

Sugiyanto, C., Kusumastuti, S. Y., \& Donna, D. R. (2012). Managing Risks: How do Poor Households Smooth Their Income and Consumption? (An Examination of Poor Households in Yogyakarta, Indonesia). Indonesia: Institute for Money, Technology and Financial Inclusion.

Suleri , A. Q., \& Savage, K. (2006). Remittances in crises: a case study from Pakistan. ondon: Overseas Development Institute.

Tapsoba, T. A. (2017). Poverty, disasters and remittances: do remittances and past disasters influence households' resilience? . Études et Documents, $n^{\circ}$ 8, CERDI. , 1-36.

UN, U. (2011). Impact of Remittance in Poverty in Developing Countries. New York and Geneva: United Nations.

UNDP, U. N. (2001). Nepal Human Development Report 2001: Poverty Reduction and Governance. Kathmandu: United Nations Development Program.

Upadhyaya, S. K. (2010). Upland Poverty in Nepal: the Role of Environment. Kathmandu, Nepal: Institute for Integrated Development Studies (IIDS).

World Bank. (2014). Large-Scale Migration and Remittance In Nepal: Issues, Challenges, And Opportunities. Poverty Reduction and Economic Management Sector Unit South Asia Region.

Yang, D. (2005). International Migration, Human Capital, and Entrepreneurship: Evidence from Philippine Migrants' Exchange Rate Shocks. Research Seminar in International Economics (p. 7). University of Michigan. 